\title{
REKONSTRUKSI MAQÂSHID AL-SYARÎ'AH (Sebuah Gagasan Hasan Hanafi tentang Revitalisasi Turâts)
}

\author{
Moh. Hefni \\ (Jurusan Syariah STA IN Pamekasan, JI. Pahlawan Km.04 Pamekasan, email: \\ desy_ira@telkom.net)
}

\begin{abstract}
A bstrak:
Dalam pergulatan wacana keagamaan kontemporer, isu maqâshid al-syarî'ah banyak dihembuskan oleh kalangan liberal sebagai sebuah simbol perlawanan atas kian teguhnya keberpihakan pada dominasi fiqih klasik yang dalam banyak hal telah gagal melampaui jamannya. Salah seorang pemikir kontemporer yang mengusung program rekonstruksi kebudayaan yang membebaskan adalah Hasan Hanafi. Ia ingin mereformasi pemikiran Islam dengan melakukan revitalisasi terhadap turâts (tradisi) klasik dan mere konstruksinya sehingga tidak usang dan menjadi ramah terhadap kondisi kontemporer. Di bidang hukum Islam, Hanafi melakukan rekonstruksi atas maqâshid al-syarî'ah melalui reformasi linguistik. Hasilnya, hifzh al-nafs dimaknai sebagai menjaga kelestarian umat dari ancaman yang datang baik dari dalam negeri ataupun luar negeri, hifzh al-'aql diaritikan menggalakkan rasioanalitas, pendidikan, dan memerangi kebodohan, hifzh al-dîn dimaknai sebagai memberi kebebasan beragama kepada pemeluk agama untuk meyakini dan melaksanan ajaran agamanya, hifzh al-'irdl berarti menjaga harga diri umat dan negara baik dari penjajahan maupun tekanan pihak luar, dan kelima hifzh almâl adalah melindungi sumber daya alam negara dan memanfaatkannya demi kepentingan rakyat. Implementasi maqâshid al-syarî'ah tersebut menjadi kewajiban negara.
\end{abstract}

\section{Kata Kunci:}

Hasan Hanafi, maqâshid al-syarî'ah, turâts, rekonstruksi, dan negara

\footnotetext{
A bstract:

In the contemporary religious discourse, the issue of maqâshid al-syarî' ah has been blown by liberal side as the symbol of fight
} 
Moh Hefni

\begin{abstract}
against the domination of classic figh (study of Islamic law) that is considered fail in responding the challenge of time. Hasan Hanafi, one of the modern thinker, carries on a program of free cultural reconstruction. He attempts to reform Islamic thought by revitalizing and reconstructing the classic turats (tradition) in order to be up-dated and kind toward contemporary condition. In the study of Islamic law, Hanafi reconstructs maqâshid alsyarî'ah using linguistic reformation. As a result, hifzh al-nafs could be interpreted to keep the everlasting humankind from the threat coming from inside and outside the country. $\mathrm{H}$ ifzh al'aql means to encourage rationality, education, and to struggle against fatuity. $\mathrm{H}$ ifzh al-dîn means to give a religious freedom for people to believe and to perform their religion teaching. $H$ ifzh al-'irdl means to keep the dignity of ummat and country from the collonialism and othe countries' preasure. $\mathrm{H}$ ifzh al-mâl is about to proctect the natural sources of a country and tu use it for the sake of its people. It is a must for the country to implement the maqâshid al-syarî'ah .
\end{abstract}

\title{
Kata kunci:
}

Hasan Hanafi, maqâshid al-syarî’ah, turâts, rekonstruction, and country

\section{Pendahuluan}

Dalam perjalanan sejarah pemikirannya, hukum Islâm ${ }^{1}$ merupakan suatu kekuatan yang dinamis dan kreatif. Hal ini dapat dilihat dari munculnya gerakan pemikiran hukum Islam mulai dari masa Khulafâ' al-Râsyidîn yang dimotori oleh Umar ibn al-Khaththâb, era Sighar Sahabat dan Tabi'in yang ditandai dengan munculnya A hl al-Ra'y yang dimotori oleh Ibrâhîm al-Nakhâ'ie hingga munculnya madzhab figh pada era Tabî' al-Tâbi'în yang memiliki corak tersendiri sesuai dengan latar belakang sosio-kultural dan politik di mana madzhab fiqh itu tumbuh dan berkembang. Perkembangan yang dinamis-kreatif ini, setidaknya-tidaknya didorong semangat

\footnotetext{
1 Istilah "hukum Islâm" merupakan istilah khas Indonesia, sebagai terjemahan dari al-figh al-Islâmi atau dalam konteks tertentu terjemahan dari al-syarî'at al-Islâmî. Ia merupakan terjemahan dari istilah yang digunakan oleh para ahli hukum Barat, yaitu Islâmic Law. Di dalam al-Qur'ân maupun al-Hadits, atau bahkan di kitab-kitab fiqh, sama sekali tidak dijumpai istilah hukum Islâm (al-hukm al-Islâmî).
} 
keagamaan, yakni eksistensi umat Muslim sebagai umat terbaik yang diutus untuk manusia, menyerukan kebaikan dan mencegah kemungkaran.2 Implikasinya, mereka diharapkan dapat membawa misi perubahan bagi kemanusiaan. ${ }^{3}$ Ini bisa dilakukan dengan pencarian makna Islâm sesuai dengan konteksnya dan menjadikan Islâm sebagai ajaran terbuka bagi munculnya beragam penafsiran. Dorongan keagamaan ini selalu eksis sepanjang sejarah Islâm dan mengambil bentuk ijtihâd. Iqbal menyebut ini sebagai prinsip gerak dalam struktur Islâm. ${ }^{4}$

Dengan berlalunya waktu, perkembangan hukum Islâm yang progresif itu akhirnya mengarah pada penutupan pintu ijtihâd, yang secara logis mengarahkan kepada kebutuhan taqlîd, yakni suatu istilah yang secara umum dimaknai sebagai penerimaan tanpa reserve atas doktrin-doktrin yang telah mapan. 5 Keadaan ini menimbulkan kegelisahan intelektual di kalangan pemikir Islam sehingga mengantarkan pada kesadaran akan pentingnya pembukaan kembali pintu ijtihâd. Namun, persoalan yang muncul kemudian adalah apakah hukum Islâm, atau Islam secara umum, itu bersifat tetap, dalam arti tidak bisa disesuaikan dengan kondisi kontemporer ataukah dalam batas-batas tertentu ia dapat berdialog realitas zaman.

Menjawab persoalan tersebut, para pemikir Muslim, mulai abad $14 \mathrm{H}$ atau abad ke-19 Masehi, terpecah ke dalam dua mainstream, yakni kaum pembaru dan kaum tradisional. Kaum pembaru berusaha menghadirkan Islam ke kancah berbagai persoalan kontemporer. Kelompok ini terbagi lagi ke dalam dua arus, yakni arus pembaruan dengan akselerasi cepat (liberal) dengan patronnya mulai dari Ali Abdur Raziq hingga yang terkini, seperti, Hasan Hanafi, Abid alJabiri, Nashr Hamid Abu Zayd dan Mohamed Arkoun;6 dan arus

2 Al-Qur'ân Surat Alî Imrân (3): 110.

3 Lihat Muhammad al-Râzî, Tafsîr al-Râzî; al- Tafsîr al-Kabîr wa M afâtih al-Ghayb (Beirut: Dâr al-Fikr, t.th.), hlm. 194-195.

4 Mohammad Iqbal, The R econstruction of Religious Thought in Islam (New Delhi: Kitab Nadj, 1982), hlm. 148.

5 Mohammad Hasbi Ash-Shiddiqie, Pengantar Hukum Islâm (Jakarta: Bulan Bintang, 1980), hlm. 80.

6 M uhammad N ur M anuty, “Islamic Studies Programs In Malaysia's Higher Learning Institutions: Responses To Contemporary Challenges Of Modernity, Globalization And Post 9/ 11", dalam Islamic Studies and Islamic Education in Contemporary Southeast A sia, (Eds) Kamaruzzaman Bustamam-Ahmad dan Patrick Jory (Kualalumpur: 
Moh Hefni

pembaruan dengan gerak lambat (moderat) yang di dalamnya terdapat nama-nama seperti Rasyid Ridha dan berlanjut hingga era Wahbah al-Zuhayli, al-Bouthi, dan Yusuf al-Qardhawi.7 Kaum pembaru ini begitu terbuka dengan pihak luar (Barat) dan berani melakukan otokritik atas khazanah turâts. Di sisi lain, terdapat kaum tradisionalis yang sama sekali menolak ide pembaruan tersebut dan mereka menanggapinya dengan penuh kecurigaan, bahkan menganggap ide pembaruan hanyalah merupakan sebuah ide besar berbau Barat yang akan menghancurkan prinsip-prinsip ajaran Islam.8 Pada sayap ini terdapat nama-nama seperti Sayyid Quthb dan Hasan al-Banna.

Yayasan Ilmuwan, 2011), hlm. 153. Pada arus ini, Armas menyebut nama-nama lain, seperti Amina Wadud Muhsin, Asghar Ali Engineer, dan Farid Esack. Lihat, Adnin Armas, "Tafsir AI-Qur'an atau Hermeneutika Al-Qur'an" dalam Jurnal Pemikiran dan Peradaban Islam ISLA M IA, Tahun I No. 1 (Muharram 1425), hlm. 38. Sedangkan Charles Kurzman menyebut nama-nama, seperti, Muhammad Sa'id al-Ashmawi, Muhammad Natsir, Fatima Mernissi, Muhammad Sahrour, dan N urcholis Madjid, berada dalam aras Islam liberal. Lihat Charles Kurzman (ed.), W acana Islam Liberal: Pemikiran Islam Kontemporer tentang Isu-isu Global (Jakarta: Paramadina bekerjasama dengan Yayasan Adikarya IKAPI dan The Ford Foundation, 2001).

7 Basri bin Ibrahim al-Hasani al-Azhari dan Wan Mohd Yusuf bin Wan Chik, "Maqasid Sharciyyah A ccording To AI-Qaradawi in theBook al-Halal wa al-Haram fi al-Islam", dalam International Journal of Business and Social Science, Vol. 2 No. 1 (January 2011), hlm. 238-254.

8 Kecurigaan ini bisa dijelaskan melalui konsep other, yakni dunia Timur atau Muslim. Kritik Said atas konsep other menemukan konteksnya di sini. Dalam konsep ini, terdapat arogansi budaya bahwa peradaban dan agama yang dianut dunia Barat adalah paling unggul, sehingga membuat pandangan yang bias terhadap posisi other. Masyarakat Barat menganggap bahwa peradaban mereka superior dan lebih maju daripada Timur. Tradisi orientalisme yang memandang inferior, monolitik, dan periferi terhadap dunia Timur adalah wujud nyata arogansi superioritas itu. Di sinilah Edward W. Said mengkritik orientalisme secara jenius, yakni corak pemikiran yang membedakan epistemologi antara Timur dan Barat. Timur dipandang sebagai "yang lain" dan pandangan ini menjadi titik tolak untuk menyusun berbagai teori, epik, novel, deskripsi sosial, dan paparan politik mengenai Timur (orang-orangnya, tabiat, pikirannya, dan seterusnya). Orientalisme, papar Said, akhirnya menjadi proyek historis-materialis sebagai jenis pengetahuan Barat yang bertujuan mendominasi, merestrukturisasi, dan mendatangkan kekuasaan atas Timur. Said dengan meminjam ide wacana Foucault menyatakan orientalisme mesti dipandang sebagai wacana untuk memahami tumbuh suburnya berbagai disiplin sistematis dengan apa kebudayaan Barat mampu mengatur, bahkan memproduksi Timur secara politis, sosiologis-antropologis, militer, ideologis, saintifik, dan imajinatif pada 
Di antara pemikir Muslim yang menarik untuk dikaji adalah Hasan Hanafi. Ia dipandang sebagai pemikir yang ikut mengambil bagian dalam pergumulan intelektual di Mesir yang disulut oleh Jamal al-Dîn al-A fgani dan Mohammad A bduh. Ia memproklamirkan gagasan Kiri Islam (al-Y asar al-Islâmi) sebagai sebuah gerakan agama yang meletakkan orang yang tertindas sebagai obyek utama yang harus dibela dan diperjuangkan. ${ }^{9}$ Kiri Islam lahir dari kesadaran penuh atas posisi tertindas kaum Muslim, untuk kemudian merekonstruksi seluruh bangunan pemikiran Islam secara menyeluruh (al-manâhij al-Islâmî al-'A mm), sehingga Islam dapat berfungsi sebagai kekuatan pembebasan. Hanafi menamai proyek ini al-Turâts wa al-Tajdîd (tradisi dan modernisasi).

Hanafi mengagendakan tiga dimensi yang saling berhubungan yang menjadi basis dalam membangun proyeknya, yaitu: Pertama, mawqifunâ min al-turâts al-qadîm (sikap kita atas khazanah klasik). Dalam program ini Hanafi ingin mereformasi pemikiran Islam dengan melakukan revitalisasi terhadap turâts klasik dan merekonstruksinya supaya tidak usang, bisa berdialog dengan, dan bermanfaat untuk zaman ini. Dimensi ini melahirkan seruan untuk merevitalisasi khazanah Islam klasik. Namun demikian, di sisi lain kebudayaan Barat telah terlanjur menghegemoni kehidupan umat Muslim. Karenanya, kebudayaan Barat juga perlu diperlakukan dengan tepat melalui program kedua, yakni mawqifunâ min al-turâts al-gharbi (sikap kita terhadap khazanah Barat). Dimensi ini

periode pasca-Pencerahan. Lihat Edward W Said, O rientalisme, terj. Asep Hikmat, (Bandung: Pustaka Salman, 1996), hlm.142.

9 Gerakan kiri Islam menggunakan dasar berpikir paradigma Marxisme. Namun, labelisasi kiri Islam yang menggunakan paradigma marxis, pada akhirnya terlabeli dengan kelompok yang anti Tuhan dan komunis yang memang memihak padakaum tertindas. Kiri Islam berupa gerakan perlawanan dan kritisisme yang menjelaskan jarak antara realitas dan idealitas. Namun, ada perbedaan yang cukup signifikan antara gerakan marxisme dan kiri Islam, kiri Islam memandang agama sabagai motivator, sedangkan marxisme memandang agama sebagai candu. Kiri Islam bukanlah Islam yang berpoleskan Marxisme, karena itu berarti menafikan makna revolusioner dari Islam sendiri. la juga tidak berarti bentuk eklektik antara Marxisme dan Islam, karena yang demikian hanya menunjukkan bentuk pemikiran yang tercerabut dari akarnya, tanpa pertautan yang erat dengan realitas kaum Muslim. Tetapi, Islam secara tegas mengusik kemapanan, baik kemapanan politik maupun agama. 
Moh. Hefni

melahirkan oksidentalisme, sebuah kajian kritis atas budaya Barat, sebagai lawan dari orientalisme. Ketiga, mawqifunâ min al-waqi' (sikap kita atas realitas,), yakni menafsirkan kembali serta merekonstruksi kebudayaan masa sekarang dalam skala global yang memosisikan Islam sebagai fondasi ideologis bagi kemanusiaan. Dimensi ketiga ini melahirkan sebuah teori penafsiran (hermeneutika). 10

Pemikiran Hanafi yang tertuang dalam berbagai tulisan, baik buku maupun artikel, telah banyak menyedot perhatian para intelektual Muslim dan Barat, seperti Muhsin Mili, Issa J. Boullata, Ali Harb, Kazuo Shimogaki, A bdurrahman Wahid, Azyumardi Azra, dan Komaruddin Hidayat, serta diskusi-diskusi serius yang diadakan LKiS dan Yayasan Paramadina semenjak tahun 1993.11 Berbagai tulisan yang mengkaji pemikirannya juga bertebaran di berbagai jurnal dan buku. Kebanyakan mereka mengarahkan pada pemikiran hermeneutika Hanafi, terutama dikaitkan dengan al-Qur'an. Di antara mereka adalah Ilham B. Saenong,12 Nia Dwi Anggraini,13 Ahmad Hasan Ridwan,14 Robi'atul Mariyah dan Ummy Kultsum, ${ }^{15}$ dan

10 Abad Badruzzaman, Kiri Islam Hasan Hanafi: M enggugat Kemapanan Agama dan Politik (Yogyakarta: Tiara Wacana, 2005), hlm. 53; Moh. N urhakim, Islam, Tradisi, dan Reformasi: Pragmatisme" Agama dalam Pemikiran Hasan Hanafi (Jawa Timur: Bayu Media Publishing, 2003), hlm. 31; dan Din Wahid, "Kiri Islam: Studi atas Gagasan Pembaruan Pemikiran Islam Hassan Hanafi", dalam Jurnal "Refleksi", Vol. 2, No.2, (2000), hlm. 38.

11 Moh. Nurhakim, Islam, Tradisi, dan Reformasi, hIm. 19

12 Ilham B. Saenong, Hermeneutika Pembebasan: M etodologi Tafsir A I-Q uran M enurut H assan Hanafi (Jakarta: Teraju, 2002). Dalam buku ini Saenong menggambarkan tentang bagaimana Hanafi melakukan refleksi kembali hakikat teks dan penafsiran, sekaligus merumuskan kerangka metodologis dalam memahami al-Qur'an, yang biasa disebut sebagai "hermeneutika Qur'an untuk pembebasan" atau disingkat sebagai "hermeneutika Pembebasan". Dalam hal ini, setiap teks dan kegiatan penafsiran diteropong berdasarkan relasinya dengan realitas dan kepentingan penafsir atas realitas tersebut. Hanafi menegaskan bahwa penafsiran Qur'an tidak bisa dipisahkan dari hubungan triadik antara teks dengan kompleksitas linguistik dan historisnya, pembaca, dan penafsir. Jika mengabaikan salah dari ketiganya, suatu penafsiran akan tercerabut dari dunia nyata dan tidak akan berbicara apa-apa kepada manusia.

13 Nia Dwi Anggraini, Hermeneutika Q ur'an H asan Hanafi: Suatu Telaah Kritis (Skripsi Fakultas IImu Pengetahuan Budaya Universitas Indonesia Jakarta, 2009)

14 A hmad Hasan Ridwan, Reformasi Intelektual Islam: Pemikiran Hasan Hanafi tentang Reaktualisasi Tradisi Keilmuan Islam (Jakarta: Ittaqa Press, 1998). Dalam mengkaji hermeneutika Qur'an, yang kali pertama adalah kesadaran historis untuk 
Rekonstruksi Macâshid al-Syarî'ah

Ahmad Khudori Sholeh. 16 Beberapa lainnya memfokuskan pada bidang teologi, di antaranya adalah Rohman. ${ }^{17}$ Sedangkan Shimogaki18 dan Badruzzamaan ${ }^{19}$ membedah pemikiran Hanafi secara utuh tentang Kiri Islam.

Dalam kaitan ini, terdapat kekosongan kajian tentang turâts kaitannya dengan hukum Islam. Karenanya, tulisan ini dihajatkan untuk mengisi kekosongan kajian tentang pemikiran Hanafi, terutama

menentukan orisinalitas kitab suci. Kedua, kesadaran eiditis yang menjelaskan dan menafsirkan makna Qur'an. Ketiga, kesadaran praktis yang menggunakan makna tersebut sebagai sebagai asar teoritik bagi tindakan dan mengantarkan wahyu pada tujuan akhirnya dalam kehidupan nyata manusia.

15 Robi 'atul Mariyah dan Ummy Kultsum, “Hermeneutika AI-Qur'an Hassan Hanafi: Membaca Teks dengan Dimensi Pembebasan". www.iainsunanampel.ac.id

16 Sholeh, A hmad Khudori, Pemikiran Islam Kontemporer, $\mathrm{H}$ asan $\mathrm{H}$ anafi: $\mathrm{H}$ ermeneutika H umanistik (Yogyakarta: Jendela. 2003). Dalam buku ini disebutkan bahwa Hanafi menggunakan hermeneutika sebagai alternatif metode interpretasi teks atas kritiknya pada metode tafsir klasik. Hanafi juga memperluas cakupan hermeneutika, dari sekedar ilmu interpretasi atau teori pemahaman, menjadi ilmu yang menjelaskan tentang penerimaan wahyu sejak tingkat perkataan hingga tingkat dunia. Hermeneutika adalah ilmu tentang proses wahyu dari huruf sampai kenyataan, dari logos sampai praksis, dan juga transformasi wahyu dari pikiran Tuhan kepada kehidupan manusia.

17 Ma'tufathu Rohman, Gagasan Reaktualisasi Pemikiran Islam Hasan Hanafi (Skripsi Fakultas Ushuluddin UIN Sunan Kalijaga Yogyakarta: 2010). Dalam penelitian ini ditemukan bahwa Persoalan Reaktualisasi Pemikiran Islam Hasan Hanafi yang diasumsikan sebagai langkah untuk memahami dunia barat sebagai upaya menutupi kekurangan dunia timur dengan cara mengkritik dunia timur dan ummat Islam, ini merupakan langkah kongkrit perjuangan Hasan Hanafi. Hasan Hanafi menjadikan gagasan reaktualisasi pemikiran Islam sebagai cermin untuk kebangkitan dunia timur dengan berkaca pada dunia barat. Dunia timur harus terbuka, sehingga belajar dan berguru pada dunia barat adalah sebuah keharusan untuk mengangkat harkat dan martabat dunia timur. Dengan demikian, maka sudah saatnya dunia barat dan dunia timur duduk satu meja untuk berdialektika yang bertujuan untuk menghindari adanya klaim bahwa dunia barat adalah musuh bagi dunia timur. Padahal bagi dunia timur, dunia barat adalah merupakan teman dan bukan musuh sehingga peradaban barat bukanlah peradaban yang superior, dan sudah saatnya dunia timur untuk mensejajarkan peradaban timur dengan peradaban barat sehingga bisa berjalan sinergis.

18 Kazuo Shimogaki, Kiri Islam: Antara M odernisme dan Postmodernisme, Telaah Kritis atas Pemikiran Hasan Hanafi, terj. M.Imam Aziz dan M. Jadul Maula (Yogyakarta: LKIS, 1993)

19 A bad Badruzzaman, Kiri Islam Hasan Hanafi: M enggugat Kemapanan Agama dan P olitik (Yogyakarta: Tiara Wacana, 2005) 
Moh Hefni

di bidang hukum Islam. Karenanya, tulisan ini mengkaji pemikiran Hanaf tentang revitalisasi maqâshid al-syarî'ah. Bagi kaum liberal, Isu maqâshid al-syarî'ah dijadikan sebagai simbol perlawanan atas kian teguhnya keberpihakan pada dominasi fikih klasik yang dalam banyak hal telah gagal melampaui jamannya.

\section{H anafi: Pengembaraan Intelektual dan Setting Sosio-Politik}

Hassan Hanafi dilahirkan di Kairo, Mesir, tepatnya di dekat Benteng Salahuddin, daerah perkampungan AI-Azhar, di mana kota ini merupakan tempat bertemunya para mahasiswa muslim dari seluruh dunia yang ingin belajar, terutama di Universitas Al-Azhar. Ia lahir dari leluhur Berber dan Badui Mesir pada 13 Februari 1935.20 Keluarganya berasal dari Bani Suwayf, sebuah provinsi yang berada di pedalaman Mesir, kemudian berurban ke Kairo, ibu kota Mesir. Ia adalah tokoh terkemuka dalam Islam modern. ${ }^{21}$ dan merupakan filusuf hukum Islam dan guru besar pada fakultas Filsafat Universitas Kairo.

Pendidikannya diawali di pendidikan dasar di Madrasah Sulaymân Ghawish, tamat tahun 1948. Setamat dari pendidikan dasar, Hanafi kecil masuk sekolah pendidikan guru, al-M u'allimîn. Kemudian melanjutkan ke Madrasah Tsanawiyah "Khalil Agha", Kairo, selesai pada tahun 1952.22 Selama belajar di tsanawiyah ini, Hanafi aktif mengikuti diskusi-diskusi yang diadakan oleh al-Ikhwân al-M uslimûn. ${ }^{23}$ Kegiatan ini membuat pemikiran Hanafi berkembang.

20 Caryle Murphy, Passion for Islam: Shaping the M odern M iddle East: The Egyptian Experience, (N ew York, Scribner, 2002), hlm. 220.

21 Richard K. Khuri, "A Critique of Hassan Hanafi Conerning his Reflections on the Scarcity of Freedom in the Arab-Muslim World" dalam Şerif Mardin, (ed.) Cultural transitions in the M iddleE ast (Leiden: E.J. Brill, 1994), hlm. 88.

${ }^{22}$ Adhmad Khudori Sholeh, "Mencermati Hermenutika Humanistik Hasan Hanafi", Jurnal Studi IImu-ilmu A lqu ran dan H adits V ol. 11, N 0. 1, (Januari 2010), hlm. 42.

23 Al-Ikhwān Al-M uslimūn berdiri di kota Ismailiyah, Mesir. Pada Maret 1928. Pendirinya adalah Hasan al-Banna, bersama keenam tokoh lainnya, yaitu Hafiz A bdul Hamid, Ahmad al-Khusairi, Fuad Ibrahim, A bdurrahman Hasbullah, Ismail Izz dan Zaki al-Maghribi. A I-Ikhwān Al-Muslimūn merupakan sebuah organisasi Islam berlandaskan ajaran Islam. Ia merupakan salah satu jamaah dari beberapa jamaah yang ada pada umat Islam, yang memandang bahwa Islam adalah dîn yang universal dan menyeluruh, bukan hanya sekedar agama yang mengurusi ibadah ritual (shalat, puasa, haji, zakat, dan sebagainya) saja. Tujuan Al-Ikhwān Al-Muslimūn adalah mewujudkan terbentuknya sosok individu muslim, rumah tangga Islami, bangsa yang Islami, pemerintahan yang Islami, negara yang dipimpin oleh negara-negara 
Bahkan ia juga mempelajari pemikiran Sayyid Qutb tentang keadilan sosial dan keislaman.

Setamat Tsanawiyah, Hanafi melanjutkan studinya di Departemen Filsafat Universitas Kairo, selesai pada tahun 1956 dengan menyandang gelar sarjana muda. Pada 11 oktober $1956 \mathrm{M}$ ia berangkat ke Perancis untuk melanjutkan studi di Universitas Sorbonne Prancis, dengan mengambil konsentrasi pada kajian pemikiran Barat pra-modern dan modern. ${ }^{24}$ Selama di Prancis, Hanafi mendalami berbagai disiplin ilmu, di antaranya adalah belajar metode berpikir (ilm manthîq), perubahan, dan sejarah dari Jean Gitton, fenomenologi dari Edmund Husserl, analisis kesadaran dari Paul Ricour, bidang perubahan pada Massignon, yang sekaligus bertindak sebagai pembimbingnya.25 Hanafi menyelesaikan program master dan doktornya pada tahun 1966, dengan tesis berjudul Les M ethodes d'Exegeses: Essei sur La Science des Fondament de La Conprehension IImu U shul Figh dan desertasi berjudul L'Exegese de La Phenomenologie, L'etat actuel de la $M$ ethode Phenomenologie et son application au Phenomene Religiux.26 Diakui oleh Hanafi bahwa kedua karya tersebut banyak dipengaruhi oleh fenomenologi Husserl. ${ }^{27}$

Karir akademiknya dimulai pada 1967 ketika ia diangkat sebagai lektor, lektor kepala pada 1973, dan profesor filsafat pada tahun 1980 di Jurusan Filsafat Universitas kairo.28 Selain itu Hanafi juga aktif memberi kuliah di beberapa negara, seperti Prancis (1969), Belgia (1970), Temple University Philadel phia A merika Serikat (1971-

Islam, menyatukan perpecahan kaum muslimin dan negara mereka yang terampas, kemudian membawa bendera jihad dan da'wah kepada Allah sehingga dunia mendapatkan ketentraman dengan ajaran-ajaran Islam. Al-Ikhwōn Al-Muslimūn menolak segala bentuk penjajahan dan monarki yang pro-Barat.

24 Hasan Hanafi, ad-Dìn wa at-T saurah fi M ișr1952-1981; al-Y amîn wa al-Y asâr fî fikri alDîn, V ol. 7 (Kairo: Maktabah Madbuli, 1989), hlm. 331-332.

25 M. Ridlwan Hambali, H assan H anafi: D ari Islam Kiri, Revitalisasi Tu rats" dalam Islam Garda Depan: Mosaik Pemikiran Islam Timur Tengah, (ed.) M. Aunul Abid Shah, (Bandung: Mizan, 2001), hlm. 219\& 221-223.

26 Disertasinya setebal 900 halaman ini dinobatkan sebagai karya tulis ilmiah terbaik dari Pemerintah Mesir pada tahun 1971. Lihat Issa J. Boullata, Trends and Issues in Contemporary A rabs Thought, (New York: SUNY Press, 1995), hlm. 98.

Ahmad Khudori Sholeh, Pemikiran Islam Kontemporer, Hasan Hanafi: Hermeneutika H umanistik (Yogyakarta: Jendela. 2003), hlm. 157

$27 \mathrm{H}$ anafi, ad-Din wa at-T saurah, hlm. 332

28 Boullata, T rends and Issues, hlm. 99. 
Moh. Hefni

1975), Universitas Kuwait (1979), Universitas Fez Maroko (1982-1984). Pada 1984-1985 ia diangkat sebagai guru besar tamu di Universitas Tokyo Jepang dan menjadi penasihat program di Universitas PBB di Jepang pada 1985-1987.

Sebagai seorang intelektual, ia banyak menghasilkan karya tulis. Pada fase awal pemikirannya itu, tulisan-tulisan Hanafi masih bersifat ilmiah murni. Baru pada awal periode 1970-an, tulisan-tulisan Hanafi lebih bersifat populis sebagai bentuk perhatiannya pada pencarian penyebab kekalahan umat Muslim dalam perang melawan Israel tahun 1967. Oleh karena itu, tulisan-tulisannya lebih bersifat populis. Pada periode tersebut, ia banyak menulis artikel di berbagai media massa, seperti al-Katib, al-A dab, al-Fikr al-M u'ashir, dan M imbar al-Islâm. Pada tahun 1976, tulisan-tulisan yang berserakan tersebut kemudian diterbitkan dalam bentuk sebuah buku dengan judul Q adhaya $M$ u'âshirat fî Fikrinâ al-M u'âshir. Buku ini memberikan deskripsi tentang realitas dunia Arab saat itu, tugas para pemikir dalam menanggapi problema umat, dan pentingnya pembaruan pemikiran Islam untuk menghidupkan kembafi khazanah tradisional Islam. Kemudian, pada 1977, ia menerbitkan buku Qadhaya M u âshirat fî al Fikr al-Gharib. Buku kedua ini mendiskusikan pemikiran para sarjana Barat untuk melihat bagaimana mereka memahami persoalan masyarakatnya dan kemudian mengadakan pembaruan.

Kedua buku itu secara keseluruhan membicarakan tentang dua pokok pendekatan analisis yang berkaitan dengan sebab-sebab kekalahan umat Islam, yakni memahami posisi umat Muslim sendiri yang lemah dan memahami posisi Barat yang superior. Kedua pendekatan inilah yang nantinya melahirkan dua pokok pemikiran baru yang tertuang dalam dua buah karyanya, yaitu al-Turâts wa alTajdîd (Tradisi dan Pembaruan), dan al-Istighrab (Oksidentalisme).

Selanjutnya adalah periode 1980-an sampai dengan awal 1990an. ketimbang masa-masa sebelumnya. Dalam periode ini, dilatarbelakangi oleh kondisi politik yang relatif lebih stabil, Hanafi mulai menulis al-Turâts wa al-Tajdîd yang terbit kali pertama pada 1980. Buku ini merupakan landasan teoretis yang memuat dasardasar ide pembaharuan dan langkah-langkahnya. Kemudian, ia 
menulis al-Yasar al-Islâmi (Kiri Islam),29 sebuah tulisan yang lebih merupakan sebuah "manifesto politik" yang berbau ideologis. Selanjutnya, ia menulis uraian secara terperinci tentang pokok-pokok pembaruan yang ia tulis dalam kedua karyanya yang terdahulu dalam buku berjudul $\mathrm{M}$ in al-A qîdah ila al-Tsawrah. Buku yang terdiri atas 5 jilid ini diterbitkan pada 1988.

Pemikirannya tersebar di dunia Arab dan Eropa. Pada 1981, ia memrakarsai sekaligus sebagai pimpinan redaksi penerbitan jurnal ilmiah al-Yasâr al-Islâmî. Pemikirannya dalam jurnal ini mendapat reaksi keras dari penguasa Mesir saat itu, Anwar Sadat, dan menyeretnya ke penjara. Keberangkatannya ke Amerika sebagai dosen tamu sebenarnya tidak lepas dari perselisihannya dengan A nwar Sadat yang memaksanya untuk meninggalkan Mesir.30

Pemikiran Hanafi, selain dibentuk oleh perjalanan intelektualnya, juga dipengaruhi oleh latar belakang sosio-politik kehidupannya. Hanafi lahir dan dibesarkan dalam kondisi masyarakat Mesir yang penuh pergolakan dan pertentangan. Dari sisi sosio-politik, saat itu terdapat dua kelompok ekstrem yang saling berebut pengaruh. Pada sayap kiri terdapat Partai Komunis yang samakin kuat berkat pengaruh Sovyet di seluruh dunia, termasuk Mesir. Kemenangan Sovyet selama perang dan dikukuhkannya perwakilan Sovyet di Kairo (1942) merangsang minat kalangan mahasiswa dan kaum muda Mesir untuk belajar komunisme. sedangkan di sayap kanan terdapat kelompok Ikhwân al-M uslimîn, yang didirikan Hassan al-Banna pada 1929 di Ismailia, yang pro Islam dan anti Barat. ${ }^{31}$ Kelompok kedua memiliki sejumlah besar pengikut, termasuk Hanafi ketika menempuh pendidikan di Tsanawiyah.

29 Hanafi menulis karya ini karena diinspirasi oleh Revolusi Iran. Dalam buku ini, ia memperkenalkan ide-ide seorang ideolog Iran, Ali Shari'ati. Lihat Mona Abaza, "Asia Imagined By The Arabs", dalam Islamic studies and Islamic education in contemporary Southeast Asia, (Eds) Kamaruzzaman Bustamam-Ahmad dan Patrick Jory (Kualalumpur: Yayasan Ilmuwan, 2011), hlm. 13-14.

30 Ilham B. Saenong, Hermeneutika Pembebasan, M etodologi Tafsir AI-Q ur'an menurut H assan H anafi (Jakarta: Teraju, 2002), hlm. 71-75

31 George Lencowski, Timur Tengah di Tengah Kancah Dunia, terj. Asgar Bixby, (Bandung: Sinar Baru, 1992) hlm. 298. Lihat juga John L. Esposito, The Oxford Encyclopaedia of the M odern Islamic W orld (New York: Oxford University Press, 1995), hlm. 98. 
Moh. Hefni

Pemerintah Mesir sendiri mengambil sikap yang tegas menyikapi pergolakan tersebut, yakni dengan melakukan pembersihan terhadap kaum komunis pada 1946, kemudian melakukan pembunuhan terhadap al-Banna, pendiri dan tokoh Ikhwân al-M uslimîn, pada 1949, setelah setahun sebelumnya melarang aktivitas kelompok ini. Pergolakan itu terus berlanjut hingga meletusnya revolusi pada 1952 yang dimotori oleh A hmad Husayn, salah seorang tokoh partai sosialis. 32 Beberapa bulan kemudian, pada tahun yang sama, sekelompok perwira muda yang dikenal dengan free officers di bawah komando Muhammad Najib mengambil kesempatan. The Free Officers merupakan kelompok rahasia yang dibentuk pada 1947, yang terdiri atas sebelas perwira dipimpin Mayor Jenderal Muhammad Najib, yang saat itu menjadi kepala staf. Dengan melakukan kudeta terhadap raja Faruq, saat situasi tidak dapat dikendalikan. Saat pengambilalihan kekuasaan ini, Najib sebenarnya menggandeng Ikhwân al-M uslimîn yang mempunyai basis kuat di kalangan masyarakat bawah. Akan tetapi, setelah ia menjadi presiden dengan Gamal Abdul Naser sebagai Perdana Menteri, Najib menendang Ikhwân al-M uslimîn karena menganggap bahwa kelompok ini sangat berbahaya terhadap kelangsungan kekuasaannya.

\section{Rekonstruksi Maqâshid al-syarî’ah}

Istilah maqâshid menempati posisi penting dalam perbincangan $\mathrm{U}$ shûl al-Figh. Istilah itu digulirkan dan digunakan oleh tokoh-tokoh seperti al-Turmudzi al-Hakim (abad III), A bû Manshûr al-Maturidî (w. 333), A bû Bakar al-Qaffal (w. 365), Abû Bakar alAbharî (w.375), al-Baqillani (w.403), dilanjutkan Imâm Haramayn, Imâm al-Ghazâlî (w. 505), al-Râzî (w. 606), Al-Amidy (w.631), Ibn Hajib (w. 646), Izz al-Dîn Abd Salam (w. 660), Baydlawî (w. 685), AlAsnawi (w. 772), Ibn Subuki (w. 771),33 dan al-Syâfi'î.34 Namun

32 Hassan Hanafi, Al-D in wa al-Tsaurah fi M ishra 1952-1981, VII, (Mesir: Maktabah Madbuli), hlm. 332.

33 A hmad al-Raysuni, N adzariyyat al-M aqâshid 'ind al-Imâm al-Syatibi, (1995), hlm. 40. Beberapa tokoh di antaranya, seperti, al-Juwayni (w. 1085), al-Ghazâli (w. 1111), alRâzî (w. 1209), al-Amidi (w. 1233), al-Salmi (w. 1261), al-Qarafi (w. 1285), Ibn Taymiyah (w. 1327), al-Shatibi (w. 1388), Ibn al-Qayyim al-Jawziyah (w. 1350), dan alTufi (w. 1316) mempergunakan istilah maqâshid al-syarî̀ah secara bergantian (interchangeably) dengan konsep mashlahah. Lihat Asyraf Wajdi Dusuki dan 
demikian, tokoh-tokoh tersebut belum menawarkan maqâshid alsyarî'ah sebagai konsep yang komprehensif. A bû al-Ma'âli al-Juwayni, misalnya, yang dikenal dengan Imam Haramayn (w. $478 \mathrm{H}$ ), melontarkan ide maqâshid al-syarî'ah sebagai konsep baru yang mempunyai kepastian dalil dan melampaui perbedaan madzhab figh dan bahkan dari ushul fiqh itu sendiri yang bersifat zhannî. Dalam kaitan ini, al-Juwayni mengungkapkan keprihatinannya akan kemerosotan peradaban sosial. Ia memberikan solusi, untuk keluar dari kondisi ini tidak ada cara selain membangun maqâshid al-syarî'ah yang universal dan mengangkatnya dari level zhannî ke level qath'î.35

Konsep maqâshid al-syarî'ah itu kemudian disistemasikan oleh al-Syathibi.36 Karenanya, wajar ketika al-Syatibi dipandang sebagai Bapak maqâshid al-syarî'ah. Ia mengatakan bahwa ajaran Islâm disyari'atkan tidak lain hanyalah untuk memelihara kemaslahatan

N urdianawati Irwani A bdullah, "M aqasid al-Shari 'ah, M aslahah, and Corporate Social Responsibility", The American Joumal of Islamic Social Sciences, Vol. 24 No.1 (2003), hlm. 25-46. Lihat juga Deina AbdelKader, "Modernity, the Principles of Public Welfare (M aslahah), and the End Goals of the Shari 'ah (M aqasid) in Muslim Legal Thought," Islam and Christian-M uslim R elations 14, no. 2 (2003), hlm. 164-174.

34 Berkaitan dengan al-Syâfi'î, Yûsûf Ahnmad Muhammad al-Badawi, misalnya, mengatakan bahwa sesungguhnya al-Syâfi'î dapat dinilai sebagai pionir dalam menggunakan konsep maqâshid al-syarî'ah. Untuk mendukung pendapatnya, Badawi menyodorkan tiga argumen: P ertama, al-Syâfi'î seringkali berbicara mengenai 'illat alhu km). Kedua, ia aktif menyuarakan pentingnya kaidah-kaidah universal (qawâ'id alkuliyyah). Dan ketiga, dalam setiap proses istinbâth al-hukm, ia tidak pernah mengesampingkan tujuan-tujuan hukum. Lebih lanjut, baca Yûsûf A hmad Muhammad al-Badawî, M aqâshid al-Syarî'ah 'inda Ibn al-Taymiyyah, (Yordan: Dâr alNafầis, 2000), hlm. 75.

35 A bd Majid al-Shoghir, al-Fikr al-U shûlî wa Isykâliyyat al-Sulthot al-IImiyyah fî al-Islâm, (Beirut: Dâr al-Muntakhob al-A rabi, 1994), hlm. 356.

36N ama lengkapnya adalah A bû Ishaq Ibrahim ibn Musa al-Lakhmi al-Syathibî. Tidak ada keterangan tentang keluarganya, tetapi dari namanya, ia diduga berasal dari suku Lakhmi. Ia hidup di Granada, sebuah kota yang daerah yang paling berpengaruh di Spanyol, terutama pada abad IV M. Nama al-Syathibî sendiri menimbulkan kontroversi di kalangan sejarawan. Beberapa kalangan menyatakan bahwa nama al-Syathibî dikaitkan dengan daerah Syathiba (Xativa atau Jativa). Karenanya mereka berkesimpulan bahwa Syathibî lahir di Syathiba, kemudian pindah ke Granada. Kesimpulan ini jelas kel iru, karena beberapa decade sebelumnya, yakni pada $645 \mathrm{H} / 1247$ M, Syathiba sudah jatuh ketangan orang-orang Kristen. Baca Mun'im A. Sirry, "Memperkenalkan Fiqh Abu Ishaq al-Syathibi”, Jurnal U lumul Qur'an, Vol. V No. 1 (1999), hlm. 81. 
Moh Hefni

umat manusia di dunia dan akhirat. ${ }^{37}$ Kemaslahatan dunia dan akhirat itu tegak di atas pemeliharaan tujuan hukum primer (dzarûriyah), ${ }^{38}$ yaitu: (1) menjaga agama (hifzh al-dîn); (2) menjaga jiwa (hifzh al-nafs); (3) menjaga akal (hifzh al-'aql); (4) menjaga keturunan (hifzh al-nasl); (5) menjaga harta (hizh al-mâl).39 Jika kemaslahatan yang bersifat dzarûriyah itu tidak terpelihara, maka dunia tidak akan terwujud. Begitu juga akhirat tidak akan terwujud tanpa dunia.

Sayangnya, proyek besar Syatibi dengan mengangkat konsep maqâshid ini tidak didukung oleh kondisi saat itu, sebuah kondisi di mana umat Muslim sedang mengalami krisis pemikiran karena kitab al-muwâfaqat yang memuat rumusan-rumusan lengkap tentang maqâshid al-syarî'ah ditulis sekitar setengah abad sebelum runtuhnya kota Granada, wilayah umat Muslim yang paling akhir di Andalusia, Spanyol. Akhirnya karya besar itu terkubur begitu saja dan tidak

37 Abû Ishaq al-Syathibî, al-M uwâfaqat fî U shûl al-Syarî'ah, Juz II (Beirut: Dâr alMa'rifah, t.th.), hlm. 6.

38 Secara hierarkhis, al-Syathibi membaga kemaslahatan ke dalam tiga tingkatan, yaitu dlarûriyât, hâjiyat, dan tahsînât. D larûriyât artinya harus ada demi kemaslahatan hamba, yang jika tidak ada, akan menimbulkan kerusakan, misalnya rukun Islâm. $\mathrm{H}$ âjiyât maksudnya sesuatu yang dibutuhkan untuk menghilangkan kesempitan, seperti rukhsah (keringanan) untuk tidak berpuasa bagi orang sakit. Tahsînât artinya sesuatu yang diambil untuk kebaikan kehidupan dan menghindarkan keburukan, seperti akhlak yang mulia, dan menutup aurat. Ibid., hlm. 4-5. Lihat juga al-Zuhaylî, U shûl al-Figh al-Islâmî, Vol. 2. (Damaskus: Dâr al-Fikr, 1986), hlm. 1046-1051.

39 Ibid. Paparan ahli ushûl al-figh atas urutan elemen maqâshid bervariasi. Menurut Ghazâlî adalah agama, jiwa, akal, keturunan, kemudian yang terakhir harta. Redaksi al-Râzî berbeda-beda, terkadang mengurutkannya dengan jiwa, harta, keturunan, agama, kemudian akal. Dalam redaksi yang lain, al-Râzî menulis dengan bentuk kata plural (jama') dan urutan yang berbeda, yakni jiwa-jiwa, akal-akal, agama-agama, harta-harta, dan keturunan-keturunan. Redaksi Qarafi juga menggunakan bentuk kata plural namun dengan urutan yang berbeda, yakni jiwa-jiwa, agama-agama, keturunan-keturunan, akal-akal, harga diri-harga diri. Syathibî mempunyai tiga redaksi yang berbeda urutannya. Al-Isnawî dalam dua redaksi juga berbeda. Dan banyak sekali redaksi-redaksi yang sangat beragam yang tidak perlu penulis jelaskan di sini. Warna-warni urutan pemaparan elemen maqâshid tersebut menimbulkan pertanyaan apakah hierarkhi elemen maqâshid berlaku pada tataran praktik operasional atau hanya redaksinal? Zaghifah menyimpulkan bahwa hierarkhi tidak berlaku pada tataran praktik operasional, karena jika hierarkhi berlaku pada tataran operasional, maka meniscayakan munculnya kesemrawutan hukum dalam perkara furu'iyyah yang justeru dapat menyebabkan maqâshid al-Syar'iyah tidak lagi menjadi nilai universal. Baca Jamâl al-Dîn 'Athiyyah, Nahwa Taf'îl M aqâshid al-Syarî'ah, (Damaskus: Dâr al-Fikr, 2001), hlm. 96-100. 
ditinjaklanjuti oleh generasi berikutnya. Baru pada $1884 \mathrm{M}$ buku almuwâfaqat mulai dikenal dan dikaji pertama kali di Tunis. Sejak itulah, orang-orang mulai mengkaji konsep maqâshid al-Syatibi.

Konsep ini dibahas kembali secara serius oleh tokoh-tokoh kontemporer,40 seperti Hasan Hanafi. Menurut pembacaan Hanafi, maqâshid al-syarî'ah menjadi popular semenjak gagalnya kaum literalis dalam mengaplikasikan teks-teks agama dengan fakta empirik. Pemahaman seperti inilah yang memicu berkembangnya fundamentalisme, radikalisme, pengkafiran berkembang dalam tubuh Islam. ${ }^{41}$ Karenanya, Hanafi menyiapkan proyek rekonstruksi Ushul al-Fiqh bagi cendekiawan Muslim, sehingga mereka mampu memosisikan mashlahah, yang merupakan fondasi formulasi syari'ah, di atas tekstualitas nash dan memberikan prioritas fakta empirik di atas nash. Ini dilakukan untuk menghadang stigma syari'at Islam memiliki karakter tekstualis dan mengabaikan al-mashlahat al- 'âmmah (kemaslahatan publik). 42

Teks-teks agama secara literal, menurutnya, sudah tak mampu lagi membendung tuntutan zaman yang mengglobal dan kompleks. Karenanya, diperlukan interpretasi yang non-literal, inklusif dan jauh dari postulat-postulat teologis. Dalam hal ini, para ilmuan menemukan bahwa maqâshid asy-syarî'ah dipandang sebagai salah satu harapan untuk menyelesaikannya.

Basis metodologis yang digunakan oleh Hanafi adalah merevitalisasi turâts klasik dan merekonstruksinya supaya bisa berdialog dengan, dan bermanfaat untuk kondisi kontemporer. Ini merupakan jawaban atas maw qifunâ min al-turâts al-qadîm (sikap kita atas khazanah klasik). Rekonstruksi, menurut Hanafi, adalah pembangunan kembali warisan-warisan Islam berdasarkan semangat modernitas dan kebutuhan Muslim kontemporer. 43 Proyek Hanafi ini

40 Tokoh lainnya adalah Ibn Asyur (1879-1973 M) yang dipandang Bapak M aqâshid Modern, Y usuf al-Qaradhawi, Thaha A bdurrahman, dan sebagainya.

41 Hasan Hanafi, M in al-N ash ilâ al-Wâqi' (Al-Qâhirah: Markaz al-Kitâb li an-Nasyr, , 2004), hlm. 7.

$42 \mathrm{lbid}, 8$

43 la menawarkan ide teologi baru, yakni bahwa teologi tidak sekedar teologi doktriner tetapi lebih merupakan ideology revolusi ideologis yang dapat memotivasi kaum muslim modern untuk bereaksi melawan despotisme dan penguasa otoriter. Lebih lanjut lihat Hasan Hanafi, M in al-A qîdah ilâ al-Tsawrah, (Kairo: Maktabah Matbuli, 1991). 
Moh. Hefni

sangat erat kaitannya dengan tipe-tipe masyarakat. 44 Pertama, tipe masyarakat tradisional. Pada tipe ini, tradisi atau khazanah klasik menjadi sumber inspirasi, sumber sistem nilai, dan argumen bagi kekuasaan. Kedua, tipe masyarakat modern, di mana tradisi dikritik tajam dan tidak lagi dianggap sebagai acuan nilai. Hanafi meniscayakan adanya titik temu antara keduanya sehingga menghasilkan pembaruan yang berarti penafsiran kembali atas khazanah klasik (turâts)45 agar sesuai dengan kebutuhan zaman.

Berdasarkan tipe-tipe masyarakat tersebut, Hanafi menjelaskan ada 3 (tiga) pendekatan terhadap khazanah klasik. 46 Pertama, pendekatan kaum tradisionalis yang beranggapan bahwa khazanah lama telah memberikan solusi atas persoalan-persoalan yang dihadapi di segala zaman (masa lalu, masa kini, dan masa depan). Kedua, pendekatan yang erat kaitannya dengan usaha-usaha pembaruan yang dimotori oleh kaum Modernis. Mereka ingin membangun sebuah "bangunan" baru di samping "bangunan" Iama yang dianggap seperti tidak mempunyai nilai sama sekali. Ketiga, pendekatan gabungan antara tradisi dan pembaruan. Sebuah pendekatan yang bermaksud mengidentifikasi kedua nilai tersebut dalam rangka mencari yang relevan dengan perubahan zaman.

Hanafi memosisikan dirinya berada pada pendekatan yang ketiga. Dalam hal ini, Hanafi menawarkan ada 2 (dua) cara dalam menafsirkan kembali khazanah Islam klasik. Pertama, reformasi bahasa (linguistik). Bahasa adalah alat untuk mengekspresikan ideide sehingga perlu direformasi agar tetap memenuhi fungsinya sebagai media ekspresi dan komunikasi. Reformasi ini dapat dilakukan secara otomatis (tilqa'iyya) ketika kesadaran berpaling dari bahasa lama kepada makna dasarnya, kemudian berusaha untuk mengekspresikan kembali makna dasar ini dengan menggunakan bahasa-bahasa yang sedang berkembang. Dengan demikian, makna yang dipegang adalah makna tradisi, sedang bahasanya adalah bahasa yang telah direformasi. Misalnya, istilah "Islam" yang

44 Hassan Hanafi, Islam in the Modern World, Vol. II (Cairo : The Anglo-Egyptian Bookshop, 1995), hlm. 105.

45 Turâts di sini dimaknai sebagai segala sesatu yang sampai kepada kita dari masa lalu dalam peradaban yang dominan, sehingga merupakan masalah yang diwarisi sekaligus masalah penerima yang hadir dalam berbagai tingkatan.

46 Din Wahid, "Kiri Islam", hlm. 53 
biasanya secara umum diartikan sebagai sebuah agama tertentu, diganti dengan makna "pembebasan". Asumsi dasar dari pandangan teologi semacam ini adalah bahwa Islam, menurut Hanafi, adalah protes, oposisi dan revolusi. ${ }^{47}$ Baginya, Islam memiliki makna ganda. Jika untuk mempertahankan status-quo suatu rezim politik, Islam ditafsirkan sebagai tunduk. Sedang jika untuk memulai suatu perubahan sosial politik melawan status-quo, maka harus menafsirkan Islam sebagai pergolakan.

Kedua, pembaruan khazanah klasik dengan mengganti obyek kajian48 dari ilmu-ilmu kelslaman tradisional yang sarat dengan latar belakang kemunculannya (budaya lingkungan pada situasi dan kondisi tertentu). Hassan Hanafi memberi contoh pada teologi (ilmu kalam). Pendekatan tradisional mendefinisikan objek dari ilmu ini adalah keesaan Tuhan. Menurut Hassan Hanafi, objek tersebut harus diganti dengan manusia, yakni kesatuan manusia. Pergantian ini akan menggiring kita untuk mengakui persamaan manusia. Dapat disimpulkan penafsiran yang bercorak transformatif sebagai hasil akhir dari rumusan praktis metodologi ini. Ilmu Kalam/ Teologi, misalnya dengan konsepnya seperti Imâmah, N aql-A ql, Khalq al-A f'al dan Tawhid, secara berurutan menjadi IImu Politik, Metodologi Penelitian, Psikologi, dan Psikilogi Sosial.

Dalam menafsirkan kembali konsep maqâshid al-syarî'ah sebagai khazanah Islam klasik, Hanafi menggunakan reformasi di bidang bahasa untuk mengekspresikan kembali makna dasar maqâshid al-syarî'ah dengan menggunakan bahasa-bahasa yang sedang berkembang dalam perspektif modernitas. Sebagai contoh, al-mâl (dalam frase hifzh al-mâl) secara liberal dimaknai oleh Hanafi sebagai aset dan harta milik masyarakat dan negara, di samping juga aset pribadi dan golongan. Dalam hal ini, al-mâl tidak saja dikebiri dengan hanya pada justifikasi bagi terjaminnya aset pribadi atau golongan semata. Inilah yang dimaksud oleh Hanafi bahwa tujuan syari'at harus disatukan dengan agenda ummat (ahdaf al-ummah). ${ }^{49}$

47 Hasan Hanafi, "Pandangan Agama tentang Tanah, Suatu Pendekatan Islam," Prisma 4, (A pril 1984), hlm. 103.

48 Din Wahid, "Kiri Islam", hlm. 46.

49 Hasan Hanafi, “Maqashid al-Syari'at wa Ahdaf al-Ummat; Qira`at fi al-Muwafaqat li al-Syathibi", Jurnal al-M uslim al-M u'ashir, Vol. 103, (2002), hlm. 98-102. 
Moh. Hefni

Secara lengkap maqâshid al-syarî'ah, atau yang juga dikenal sebagai al-dlaruriyat al-khamsah, yang menjadi tumpuan bagi pelaksanaan agenda ummat tersebut adalah sebagai berikut: Pertama, memelihara kehidupan (hifzh al-nafs), yang berarti menjaga kelestarian umat dari ancaman yang datang baik dari dalam ataupun luar negeri. Kedua, menjaga akal (hifzh al-'aql), berarti menggalakkan rasioanalitas, pendidikan, dan memerangi kebodohan. Ketiga, menjaga agama (hifzh al-dîn), berarti memberi kebebasan beragama kepada pemeluk agama untuk meyakini dan melaksanan ajaran agamanya. Keempat, menjaga kehormatan (hifzh al-'irdl), yakni menjaga harga diri umat dan negara baik dari penjajahan maupun tekanan pihak luar. Kelima, menjaga harta (hifzh al-mâl), yakni melindungi sumber daya alam negara dan memanfaatkannya demi kepentingan rakyat.50

Pelaksanaan maqâshid al-syarî'ah di atas tidak terlepas dari peran negara, bahkan mereka menjadi kewajiban negara untuk menegakkannya. Negara, dalam pandangan Hanafi, bukan hanya menjamin pelaksanaan undang-undang, tetapi juga berkewajiban menegakkan maqâshid al-syarî'ah (the spirit of the law).51 Negara menjadi satu-satunya agen bagi masyarakat Muslim untuk merealisasikan tujuan keadilan distributif secara umum. Di sini, menurutnya, keterlibatan civil society yang terorganisasi menjadi sebuah kewajiban, bukan sebuah pilihan. Implikasinya, civil society tersebut secara otomatis menggantikan posisi negara atau bertindak atas nama negara apabila negara gagal memerankan dirinya sebagai sebagai agen. 52

Deskripsi di atas menunjukkan bahwa Hanafi sesungguhnya tidak mempersoalkan bentuk dan sistem negara dan pemerintahan, apakah itu negara Islâm atau bukan, apakah menganut sistem pemerintahan monarkhi, demokrasi, atau lainnya. Yang terpenting,

50 lbid.

51 Sebagaimana dikutip oleh Lily Zakiyah Munir, Islam and Politics, makalah dipresentasikan pada the International Seminar on "Islam and Universal Values: Islam's Contribution to the Construction of a Pluralistic World,", yang diadakan oleh the Embassy of Switzerland di Jakarta, 18 Maret 2004.

52 Hasan Hanafi, "Alternative Conceptions of Civil Society: A Reflective Islamic A pproach", dalam S. Chambers, dan W. Kymlicka, (eds.), A Iternative Conceptions of Civil Society, (Princeton NJ: Princeton University Press, (2002), 182. 
menurut penulis, adalah bagaimana negara itu mengikuti prinsipprinsip Islam. Kalau mengandaikan negara Islam yang berkewajiban melaksanakan tujuan-tujuan hukum Islam, tentu kaum Muslim akan mengalami banyak kesulitan. Karena, menurut An-Na'im, negara Islam sebagai sebuah institusi politik secara konseptual tidak mungkin, secara historis tidak akurat, dan secara praktis tidak bisa dilaksanakan saat ini.53

\section{Penutup}

Gagasan Hanafi tentang rekonstruksi maqâshid al-syarî'ah berada dalam lingkup besar pemikirannya tentang kiri Islam (al-yusar al-Islâmi), dalam dimensi mawqifunâ min al-turâts al-qadîm (sikap kita atas khazanah klasik). Tujuan besar pemikiran ini adalah untuk membangunkan kesadaran kaum Muslim atas posisinya yang tertindas dengan cara merekonstruksi seluruh bangunan pemikiran Islam secara menyeluruh sehingga Islam dapat berfungsi sebagai kekuatan pembebasan. Di Barat, gerakan ini hapir sama dengan gerakan Marxisme yang berusaha membangunkan kesadaran kaum proletar (tertindas) atas hegemoni kaum borjuis (pemilik modal). Wallâh a'lam bi al-shawâb.

\section{D aftar Pustaka}

Abaza, Mona. "Asia Imagined By The Arabs", dalam Islamic studies and Islamic education in contemporary Southeast Asia, (eds) Kamaruzzaman Bustamam-Ahmad dan Patrick Jory. Kualalumpur: Yayasan IImuwan, 2011.

AbdelKader, Deina. "Modernity, the Principles of Public Welfare (M aslahah), and the End Goals of the Shari ah (Maqasid) in Muslim Legal Thought," Islam and Christian-M uslim Relations 14, no. 2 (2003), hlm. 164-174.

53 Abdullahi Ahmed An-Na'im, “Civil Rights in Islamic Constitutional Tradition: Shared Ideals and Divergent Regimes", The John M arshall Law Review, No. 2 (1992), hlm. 76-98. 
Moh. Hefni

Anggraini, Nia Dwi Hermeneutika Qur'an Hasan Hanafi: Suatu Telaah Kritis. Skripsi Fakultas IImu Pengetahuan Budaya Universitas Indonesia Jakarta, 2009.

An-Na'im, Abdullahi Ahmed. "Civil Rights in Islamic Constitutional Tradition: Shared Ideals and Divergent Regimes", The John M arshall Law Review, No. 2 (1992)

Armas, Adnin. "Tafsir Al-Qur'an atau Hermeneutika Al-Qur'an" dalam Jurnal Pemikiran dan Peradaban Islam ISLAM IA, Tahun I No. 1 (Muharram 1425)

Ash-Shiddiqie, Mohammad Hasbi. Pengantar Hukum Islâm. Jakarta: Bulan Bintang, 1980.

'A thiyyah, Jamâl al-Dîn. N ahwa Taf'îl M aqâshid al-Syarî' ah. Damaskus: Dâr al-Fikr, 2001.

Azhari, Basri bin Ibrahim al-Hasani al- dan Wan Chik, Wan Mohd Yusuf bin. "Maqasid Sharciyyah According To AI-Qaradawi in the Book al-Halal wa al-Haram fi al-Islam", dalam International Journal of Business and Social Science, Vol. 2 No. 1 (January 2011), hlm. 238-254.

Badawî, Yûsûf A hmmad Muhammad al-. M aqâshid al-Syarî'ah 'inda Ibn al-Taymiyyah. Yordan: Dâr al-N afâ ìs, 2000.

Badruzzaman, Abad. Kiri Islam Hasan Hanafi: M enggugat Kemapanan A gama dan Politik. Yogyakarta: Tiara Wacana, 2005.

Boullata, Issa J. Trends and Issues in Contemporary A rabs Thought,. New York: SUNY Press, 1995.

Dusuki, Asyraf Wajdi dan Abdullah, Nurdianawati Irwani. "M aqasid al-Shari'ah, M aslahah, and Corporate Social Responsibility", The A merican Journal of Islamic Social Sciences, Vol. 24 No.1 (2003), hlm. 25-46.

Esposito, John L. The Oxford Encyclopaedia of the M odern Islamic W orld. New York: Oxford University Press, 1995.

Hambali, M. Ridlwan. Hassan Hanafi: Dari Islam Kiri, Revitalisasi Turats" dalam Islam Garda Depan: M osaik Pemikiran Islam Timur Tengah, (ed.) M. Aunul A bid Shah,. Bandung: Mizan, 2001. 
Hanafi, Hasan. "Alternative Conceptions of Civil Society: A Reflective Islamic Approach", dalam S. Chambers dan W. Kymlicka, (eds.), Alternative Conceptions of Civil Society,. Princeton NJ: Princeton University Press,. 2002., hlm. 171-189.

Hanafi, Hasan. "Maqashid al-Syari'at wa Ahdaf al-Ummat; Qira 'at fi al-Muwafaqat li al-Syathibi", Jurnal al-M uslim al-M u'ashir, Vol. 103, (2002), hlm. 65-102

Hanafi, Hasan. “Pandangan Agama tentang Tanah, Suatu Pendekatan Islam," Prisma 4, (A pril 1984)

--------. ad-Dìn wa at-Tsaurah fi M iṣr1952-1981; al-Yamîn wa al-Yasâr fî fikri al-D în, V ol. 7. Kairo: Maktabah Madbuli, 1989.

--------. M in al-A qidah ila al-Tsawrah,. Kairo: Maktabah Matbuli, 1991.

-------. Al-D in wa al-T saurah fi M ishra 1952-1981, VII. Mesir: Maktabah Madbuli.

Islam in the Modern World, Vol. II. Cairo : The Anglo-Egyptian Bookshop, 1995.

--------. M in al-N ash ilâ al-Wâqi'. Al-Qâhirah: Markaz al-Kitâb li anNasyr, 2004.

Iqbal, Mohammad. The Reconstruction of Religious Thought in Islam. New Delhi: Kitab Nadj, 1982.

Khuri, Richard K. "A Critique of Hassan Hanafi Conerning his Reflections on the Scarcity of Freedom in the Arab-Muslim World" dalam Şerif Mardin, (ed.) Cultural transitions in the M iddle E ast. Leiden: E.J. Brill, 1994. hlm. 86-115

Kurzman, Charles (ed.). Wacana Islam Liberal: Pemikiran Islam Kontemporer tentang Isu-isu Global. Jakarta: Paramadina bekerjasama dengan Yayasan Adikarya IKAPI dan The Ford Foundation, 2001.

Lenczowski, George. Timur Tengah di Tengah Kancah Dunia, terj. Asgar Bixby. Bandung: Sinar Baru, 1992.

Manuty, Muhammad Nur. "Islamic Studies Programs in Malaysia's Higher Learning Institutions: Responses to Contemporary 
Moh. Hefni

Challenges of Modernity, Globalization And Post 9/ 11", dalam Islamic Studies and Islamic Education in Contemporary Southeast A sia, (Eds.) Kamaruzzaman Bustamam-A hmad dan Patrick Jory. Kualalumpur: Yayasan IImuwan, 2011. hlm. 137-158

Mariyah, Robi'atul dan Kultsum, Ummy. “Hermeneutika AI-Qur'an Hassan Hanafi: Membaca Teks dengan Dimensi Pembebasan".

Munir, Lily Zakiyah. Islam and Politics, makalah dipresentasikan pada the International Seminar on "Islam and Universal Values: Islam's Contribution to the Construction of a Pluralistic World,", yang diadakan oleh the Embassy of Switzerland di Jakarta, 18 Maret 2004.

Murphy, Caryle. Passion for Islam: Shaping the M odern M iddle East: The Egyptian Experience,. N ew York, Scribner, 2002., hlm. 220.

Nurhakim, Moh. Islam, Tradisi, dan Reformasi: Pragmatisme" Agama dalam Pemikiran $\mathrm{H}$ asan $\mathrm{H}$ anafi. Jawa Timur: Bayu Media Publishing, 2003.

Raysuni, A hmad al-. Nadzariyyat al-maqasid 'ind al-Imam al-Syatibi. 1995.

Râzî, Muhammad al-. Tafsîr al-Râzî; al- Tafsîr al-Kabîr wa M afâtih alGhayb. Beirut: Dâr al-Fikr, t.th.

Ridwan, Ahmad Hasan. Reformasi Intelektual Islam: Pemikiran Hasan $\mathrm{H}$ anafi tentang Reaktualisasi Tradisi Keilmuan Islam. Jakarta: Ittaqa Press, 1998.

Rohman, Ma'tufathu. Gagasan Reaktualisasi Pemikiran Islam Hasan Hanafi. Skripsi Fakultas Ushuluddin UIN Sunan Kalijaga Yogyakarta: 2010.

Saenong, Ilham B. Hermeneutika Pembebasan, M etodologi Tafsir AlQ ur'an menurut H assan H anafi. Jakarta: Teraju, 2002.

Saenong, Ilham B. H ermeneutika Pembebasan: M etodologi Tafsir A I-Q uran M enurut $\mathrm{H}$ assan $\mathrm{H}$ anafi. Jakarta: Teraju, 2002.

Said, Edward W. Orientalisme, terj. Asep Hikmat,. Bandung: Pustaka Salman, 1996. 
Shaghir, Abd Majid al-. al-Fikr al-U shulî wa Isykâliyyat al-Sulthat alIlmiyyah fî al-Islâm. Beirut: Dar al-Muntakhob al-A rabi, 1994.

Shimogaki, Kazuo. Kiri Islam: A ntara M odernisme dan Postmodernisme, Telaah K ritis atas Pemikiran $\mathrm{H}$ asan Hanafi, terj. M.Imam Aziz dan M. Jadul Maula. Yogyakarta: LKIS, 1993.

Sholeh, Achmad Khudori. "Mencermati Hermenutika Humanistik Hasan Hanafi", Jurnal Studi IImu-ilmu A lquran dan Hadits V ol. 11, N o. 1, (Januari 2010)

Sholeh, A hmad Khudori. Pemikiran Islam Kontemporer, Hasan Hanafi: H ermeneutika H umanistik. Yogyakarta: Jendela. 2003.

Sirry, Mun'im A. "Memperkenalkan Figh Abu Ishaq al-Syathibi", Jurnal U lumul Qur'an, Vol. V No. 1 (1999).

Syathibî, Abû Ishaq al-. al-M uwâfaqat fî U shûl al-Syarî'ah, Juz II. Beirut: Dâr al-Ma'rifah, t.th.

Wahid, Din. "Kiri Islam: Studi atas Gagasan Pembaruan Pemikiran Islam Hassan Hanafi", dalam Jurnal "Refleksi", Vol. 2, No.2, (2000)

Zuhaylî, Wahbah al-. U shûl al-Figh al-Islâmî, Vol. 2. Damaskus: Dâr alFikr, 1986 